\title{
Bovine mastitis: a persistent and evolving problem requiring novel approaches for its control - a review
}

\author{
Miroslav Benić1, Nino Maćešić2 ${ }^{2}$ Luka Cvetnić' Boris Habrun $^{1}$, \\ Željko Cvetnić1, Romana Turk ${ }^{3}$, Dražen Đuričićc ${ }^{4}$, Martina Lojkić \\ Vesna Dobranić ${ }^{5}$, Hrvoje Valpotić ${ }^{6}$, Juraj Grizelj ${ }^{2}$, Damjan Gračner ${ }^{7}$, \\ Jozo Grbavac ${ }^{8}$, and Marko Samardžija ${ }^{2 *}$ \\ ${ }^{1}$ Department for Bacteriology and Parasitology, Croatian Veterinary Institute, Zagreb, Croatia \\ ${ }^{2}$ Clinic for Reproduction and Obstetrics, Faculty of Veterinary Medicine University of Zagreb, \\ Zagreb, Croatia \\ ${ }^{3}$ Department of Pathophysiology, Faculty of Veterinary Medicine, University of Zagreb, Zagreb, Croatia \\ ${ }^{4}$ Veterinary Practice Đurđevac, Đurđevac, Croatia \\ ${ }^{5}$ Department of Hygiene, Technology and Food safety, Faculty of Veterinary Medicine, University of Zagreb, \\ Zagreb, Croatia \\ ${ }^{6}$ Department for Nutrition and Animal husbandry, Faculty of Veterinary Medicine, University of Zagreb, \\ Zagreb, Croatia \\ ${ }^{7}$ Clinic for Internal diseases, Faculty of Veterinary Medicine University of Zagreb, Zagreb, Croatia \\ ${ }^{8}$ Faculty of Agriculture and Food biotechnology University of Mostar, Mostar, Bosnia and Herzegovina
}

\begin{abstract}
BENIĆ, M., N. MAĆEŠIĆ, L. CVETNIĆ, B. HABRUN, Ž. CVETNIĆ, R. TURK, D. ĐURIČIĆ, M. LOJKIĆ, V. DOBRANIĆ, H. VALPOTIĆ, J. GRIZELJ, D. GRAČNER, J. GRBAVAC, M. SAMARDŽIJA: Bovine mastitis: a persistent and evolving problem requiring novel approaches for its control - a review. Vet. arhiv 88, 535-557, 2018.
\end{abstract}

\section{ABSTRACT}

Mastitis in dairy cows is the inflammation of the mammary gland, and is the most important cause of economic losses in the modern dairy industry. Bovine mastitis is often infectious and can be caused by some 150 microbial species. The environment of the dairy cow is heavily colonized by microbiota, while milk is an ideal medium for propagation of the bacteria and causative agents. Staphylococcus aureus is the most common pathogen isolated from the mammary gland capable of causing health disorders in humans. Milk from an infected mammary gland has a different chemical composition compared to milk from healthy cows. Certain differences, such as protein components specific to inflamed tissue, are currently being considered in

\footnotetext{
${ }^{*}$ Corresponding author:

Prof. Dr. Marko Samardžija, Clinic for Reproduction and Obstetrics, Faculty of Veterinary Medicine, University of Zagreb, Heinzelova 55, 10000 Zagreb, Croatia; Phone: +385 12390 2321; Fax: +385 1244 1390; E-mail: smarko@vef.hr
} 
M. Benić et al.: Bovine mastitis: a persistent and evolving problem requiring novel approaches for its control

the development of diagnostic tools for mastitis. The known risk factors for mastitis can result in mastitis at the quarter, cow and herd levels. Mastitis treatment includes both preventive and therapy measures, and is primarily based on the use of antibiotics. Recent approaches to mastitis therapy have been focused on the design and use of natural therapeutics, such as zeolites, ozone and propolis, that could serve as alternatives to antibiotics.

Key words: mastitis; current knowledge; novel approaches; dairy cow

\section{Introduction}

Mastitis is inflammation of the mammary gland and is the most significant cause of economic losses in the modern dairy industry. Direct losses occurring due to mastitis include: costs of medication, veterinary services, discarded milk, and additional care of diseased animals, and in some severe cases, the death of the animal. Indirect losses include: decreased milk yield, decreased milk quality due to changes in milk chemical content, shorter productivity duration of dairy cows, earlier onset of the dry period, and decreased subsidies due to inferior milk quality (GRAČNER et al., 2006; PETROVSKI et al., 2006). Mastitis is also associated with other health disorders in cows, such as reproductive disorders and decreased feed intake, which can be reflected in decreased milk yield.

\section{Aetiology of bovine mastitis}

Mastitis is most frequently infectious, and is caused by bacteria, fungi, moulds and algae. Non-infectious mastitis is induced by mechanical causes, such as being hit by a horn, udder injuries and others. Few infective diseases can compare to mastitis in terms of the number of potential causative agents. The recent literature lists some 150 known causative agents of mastitis, and this number is very likely to increase (SHAHEEN et al., 2016). Namely, with the application of molecular identification methods, the number of causative agents isolated from secretions in inflamed mammary glands will only increase. Numerous species of microbiota present in the animal environment are able to cause inflammation of the mammary gland, if all the circumstances for infection are present. Multiple factors are at play in the aetiology of mammary gland infection, and mastitis is often the result of the interaction between the causative agent, the cow and the environment (TOPOLKO and BENIĆ, 1997). The animal environment abounds in microbiota, and milk is an ideal substrate for the growth of a multitude of bacterial species.

However, to infect an animal, the causative agent needs to overcome both the nonspecific and specific defense mechanisms of the host. The causative agents of mammary gland inflammation most frequently penetrate through the teat canal, and rarely enter via the lymphatic or circulatory systems. The only mechanical barrier between the outside world, full of potential causative agents of mastitis, and the interior of the udder is the teat canal, which is just a few millimetres in length. In lactating cows, this canal is opened 
during milking to release milk from the teat cistern. The speed of milk release from the udder is influenced by the diameter of the teat canal. In dairy cow breeds, selection factors also include milking characteristics, i.e. faster release of milk from the udder during milking (LAUREANO et al., 2012). Thus, a wider teat canal shortens the time needed for milking, but presents an increased risk for spontaneous milk leakage and the incidence of mastitis (LEE and CHOUDHARY, 2006; TÄNAVOTS et al., 2015).

\section{Zoonotic causative agents of mastitis}

Due to its chemical composition, milk is an ideal base for the growth and reproduction of a wide range of bacterial species. Therefore, milk is an important vector for transmission of disease to humans. Virtually all environmental microbial species capable of causing tissue infection are able to infect the mammary gland. Staphylococcus aureus is the most commonly isolated causative agent of mastitis worldwide (PETERSSON-WOLFE, 2010; MAĆEŠIĆ et al., 2012).

The prevalence of infection caused by this bacterial species ranges from $2 \%$ to over $50 \%$, and is directly correlated to the level of milking hygiene (PAVLAK et al., 2008; CVETNIĆ et al., 2016). Clinical symptoms vary from mild cases with increased somatic cell counts as the only indicator of infection, to gangrenous and septicaemic forms, with a lethal outcome. One infected animal can secrete the causative agent during multiple lactations if the infection becomes chronic, in which clinical episodes may arise with local signs of infection (PETERSSON-WOLFE, 2010). S. aureus produces toxins that directly damage the secretory tissues of the mammary glands. In the affected mammary gland tissue, the causative agent creates "pocket" infections that create abscesses bound by connective tissue. Within the abscesses, bacteria remain protected from the activity of antibiotics, which is one of the reasons for the poor effects of treatment. S. aureus is able to avoid antibiotics by taking up residence within the neutrophilic leukocytes and other cells of the immune system. The phagocytic bacterial cells survive within the phagocytes, thanks to this avoidance mechanism. Following phagocyte death, the bacteria are released and the process of infection continues (PETERSSON-WOLFE, 2010).

\section{The public health significance of the bacterium $S$. aureus}

Staphylococcus infections are among the most common causes of food poisoning in the world. In a four-year study conducted in 17 countries around the globe, it was found that the highest incidence of Staphylococcus-caused disease was found in Cuba, Hungary and Finland, with 58.5 cases per 10 million people (WONG and BERGDOLL, 2002). In more massive outbreaks of Staphylococcus poisoning, the sources of poisoning were dairy products, made from pasteurised and unpasteurised milk (BENIĆ et al., 2012c). 
M. Benić et al.: Bovine mastitis: a persistent and evolving problem requiring novel approaches for its control

The first documented evidence of food poisoning caused by Staphylococcus enterotoxin dates back to 1929. Since then, more than 20 types of enterotoxins have been identified. The incidence of isolating strains that carry one or more coding genes for the enterotoxin ranges from $20-100 \%$, depending on the source from which the bacteria is isolated, and the geographic origin (LARSEN et al., 2002; OMOE et al., 2002; ZSCHÖCK et al., 2005). With improved growth detection methods, the number of isolates from cow's milk, in which the enterotoxin creating gene is present, has also increased, emphasizing that milk is a potential source of Staphylococcus enterotoxin.

The literature to date has indicated the fact that intramammary infections caused by $S$. aureus present a risk for the appearance of enterotoxins in milk and dairy products. Until the 1960s, Streptococcus agalactiae was considered the most significant causative agent of mastitis in cows. With the application of preventative measures and the use of antibiotics, the frequency of mastitis caused by this bacterium was markedly reduced, and was completely eradicated from numerous herds. In humans, this bacterium causes bacteraemia, skin and soft tissue infections, urinary organ infections, and the most significant issue is its role as a causative agent in infections among newborns. The genetic similarity between strains isolated from humans and cows has been examined in several studies, with genetic diversity confirmed between strains of different origins, indicating the adaptability of the strain to the host (ZADOKS et al., 2011). The main criticism of these studies, however, was that the animal and human strains were not isolated at the same time.

In recent studies examining strains from humans and cows isolated in the same time period, it was found that $54 \%$ of the tested strains belonged to the population of causative agents present in both groups of hosts. The authors concluded that transmission is thus possible between humans and animals, or that both groups had been exposed to an external source of infection. The possible transfer between animals and humans includes direct contact between humans and animals, exposure of humans to cow faeces, or the consumption of raw milk. The public health significance of milk consumption in the transmission of $S$. agalactiae to humans in Europe is negligible, as milk is pasteurised prior to its release to the market. However, consideration should be given to dairy products made from unpasteurised cow and sheep milk (LYHS et al., 2016).

Gastrointestinal infections are among the most common zoonoses associated with cattle. Numerous bacterial species that cause food poisoning in humans have been isolated from milk, such as Listeria, the enterohaemmorhagic E. coli, Salmonella, Streptococcus, Yersinia, Shigella, and Campylobacter. These causative agents may be present in dairy products due to improper handling or inadequate preparation of food (SHAHEEN et al., 2016). 
M. Benić et al.: Bovine mastitis: a persistent and evolving problem requiring novel approaches for its control

Among the bacterial causes of mastitis that can also cause systematic health problems in humans, numerous cases of brucellosis, leptospirosis and infections caused by Trueperella pyogenes have been documented. Humans may also become infected from unpasteurised milk or from products made from milk that is not heat treated (DHANASHEKAR et al., 2012).

\section{The role of milking devices in the aetiology of mastitis}

The milking device is a key tool in efficient and economic modern milk production. The function of the milking device is to maximise milk production per cow, to extract the most milk possible from the udder in a short time period, to prevent possible damage to the teat canal, teat tissue and udders, and to avoid possible harmful impacts on the chemical composition of milk. Milk yield and the rate of milk release is best when cows are calm and experience uniform daily routine procedures during the daily milking (LEE and CHOUNDARY, 2006).

The milking device is one of the most exploited devices on a dairy farm, and may also be associated with the incidence of mastitis, somatic cell count and microorganism counts in milk. There are multiple ways in which milking devices can impact the appearance of mastitis in the herd.

The causative agents of mastitis may be mechanically transferred from cow to cow via the milking device. Additionally, they may also be transferred from one quarter to another within the same cow. In both cases, the infection is transmitted via the backflow of milk. The liners of the teat cups are the only parts of the milking device in direct contact with the animal. Since these liners are made of rubber or silicon, and they are washed and disinfected daily, the liner surface becomes damaged and requires regular replacement. S. aureus from an infected mammary gland can be transmitted to 6 to 8 other cows milked using the same milking device. This risk of transmission is even higher if the liner surface is coarse or damaged (MEIN, 2012).

Damage to the teat canal is a risk factor for the appearance of infection, since this is the first line of defence from infection. Damage to the skin on the teats is a suitable place for the multiplication of causative agents, such as $S$. aureus and $S$. dysgalactiae (BLOWEY and EDMONDSON, 2010). Due to the presence of such skin damage, disinfection after milking does not achieve the desired effect, and quarters with abrasions on the skin are more prone to infection. (BLOWEY and EDMONDSON, 2010).

Hyperkeratosis of the tip of the teat is a specific form of damage that increases the chances of infection. It appears as a prominent smooth or coarse ring around the outer opening of the teat canal. Hyperkeratosis causes the slow or incomplete opening of the teat cups, improper work of the pulsator, difficulties in removing the cups following the end 
of milking, dry milking and excessive vacuum levels (BLOWEY and EDMONDSON, 2010).

The backflow of milk is the return of drops of secreted milk from the collector back into the teat canal. Due to the intake of air between the tip of the teat liners and the teat, there is a difference in the vacuum level between the collector and the tip of the teat. Due to the difference in the vacuum level, drops achieve a speed that enables their return back into the teat canal. If those milk drops contain the causative agent, there is a chance of the development of infection. This occurs near the end of milking, and so the negative effects of milk backflow are twofold. The teat canal is completely open and therefore there is no barrier preventing the entrance of milk drops into the teat canal, and since little milk remains in the udder, there is a high likelihood that the drops that re-enter the teat canal from backflow will remain until the next milking, giving the bacteria time to multiply (MEIN et al., 2004).

The return forces that enable the movement of milk drops towards the teat opening, in combination with poor milking preparation, can result in an increased incidence of clinical mastitis. The risk of the appearance of clinical mastitis is increased if cows are milked with soiled teats, or if the teats have been washed but not dried (REINEMANN, 2010).

Colonisation of the teat canal. The current created by the flow of milk during milking causes the separation of excess keratin from the surface of the teat canal. As keratin is a suitable site for adhesion of bacteria, as the keratin breaks off, the bacteria go with it. If the milk flow is slowed or weakened due to the faulty operation of the milking device, the separation of excess keratin is slowed or disabled, which results in colonisation of the teat canal and resulting infection. This is the reason for the increased incidence of infection in cows milked only once daily, in comparison to those milked twice or three times per day (RÉMOND and POMIÈS, 2005).

Incomplete milking or over-milking. If the milking device is properly set, the duration of milking extended by 5 minutes (over-milking) will not lead to an increased risk of infection of the mammary gland (BLOWEY and EDMONDSON, 2010). However, if the device is not functioning properly, or is not properly set, every stoppage of milk after milking represents a risk of infection. The negative effects of incomplete milking are pronounced, particularly in the case of infection with $S$. agalactiae. The bacteria continue to multiply in the milk remaining in the udder between two milking sessions, and the bacterial count rises.

The effects of low voltage electrical current should also not be ignored even if they occur occasionally. Low voltage electricity has a negative effect on animals, which is seen in changes to behaviour as cows avoid entering the milking stall, or there is an increased frequency of urination or defecation. Cows will often try to knock the milking device 
off the udder with their legs. The consequences of such behaviour include disturbances to the milking routine, weaker release of milk, faecal contamination of the milking stall, increased incidence of mastitis, increased somatic cell count, and bacteria in the milk (REINEMANN, 2012).

The conclusion that can be drawn from the available literature is that the role of the milking device in the occurrence of mammary gland infections is small or negligible. Most mammary gland infections are the result of other factors, and only some $20 \%$ of new intramammary infections in the herd can be directly or indirectly attributed to the use of a milking device. In order to protect the health of the mammary gland, it is important to protect the integrity of the mammary tissues, and the teat canal and opening. The pulsation cycle, which ensures effective teat massage during milking, has resulted in a decrease in the number of new infections (MEIN et al., 2004).

\section{The pathogenesis of mastitis}

Bacteria that penetrate into the milk glands subsequently colonise the tissue and begin to multiply. With their metabolites formed at the site of multiplication, this causes an inflammatory reaction, and the affected tissues begin to release inflammation mediators. These mediators attract the leukocytes, which begin to migrate to the site of the inflammation (RUEGG, 2003). Depending on the causative agent, the extent of the infected tissue and the immunocompetence of the host, the milk gland is quickly infiltrated by leukocytes (RAINARD and RIOLLET 2006).

The cow's defence mechanisms against mammary gland infection include milk components with bactericidal activity, such as lysozyme, lactoferrin and peroxidase. The humoral (specific antibodies) and cellular defence system (somatic cells) both play an important role in combating pathogenic microorganisms in the mammary gland (EZZAT ALNAKIP et al., 2014).

\section{The epidemiology of mastitis}

Given the large number of possible causative agents of mastitis, there are several approaches to their classification. One approach categorises the agents, on the basis of their incidence and the damage they cause, into one of two groups: major and minor (VAKKAMÄKI et al., 2017). The classical division based on taxonomy breaks causative agents into their taxonomic groups: bacteria, fungus and mould, algae and viruses. Bacteria are further categorised into Gram-positive and Gram-negative, and then further into their respective genera and species.

Causative agents can be categorised into two groups based on common epidemiological properties: contagious and conditional environmental pathogens. In terms of the numbers of species, the group of contagious agents is small, and most authors include Streptococcus 
agalactiae, Staphylococcus aureus and Mycoplasma sp. in this group (BAČIĆ, 2009). The reservoir of contagious agents causing mastitis is the infected mammary gland. Infection with contagious agents most often occurs during milking. The group of environmental pathogens includes all other causative agents. The reservoir of environmental pathogens is the animal's environment, and infection occurs between milkings, though after the initial infection in the herd, some of these agents can then be transmitted from cow to cow during milking (ARGAW, 2016).

Mastitis appears in two forms: as a clinical form with visible clinical symptoms, and as a subclinical form, in which an increased somatic cell count is the only sign of infection (SEARS and McCARTHY, 2003). In most herds, the subclinical form is more common, and it is estimated that the prevalence of subclinical mastitis is 15 to 40 times higher than the clinically visible forms. The clinical form of mastitis is associated with the type of causative agent, i.e. the species S. uberis (may be also contagious), E. coli, Klebsiella, Pseudomonas and pyogenic bacteria give rise to the clinical form. Unlike this group, $S$. agalactiae, members of the genus Enterococcus coagulase negative staphylococci primarily cause subclinical forms of infection. S. aureus, as the most commonly isolated cause of mastitis, maycause both forms of mastitis (PETERSSON-WOLFE, 2010).

The risk factors for the appearance of mastitis are numerous, and may be observed as risk factors for the quarter, the cow and the herd (NYMAN et al., 2007; BREEN et al., 2009). Among the risk factors at the quarter level, there is a confirmed correlation between infection incidence and the anatomical position of the quarter, damage to the udder skin, the condition of the teat canal and the distance from the tip of the teat to the floor surface (GUARÍN et al., 2017). A higher incidence of mastitis has been observed in the hind quarters of the udder, in cows with damage to the skin of the teats, and in cows with hyperkeratosis of the teat orifice (NEIJENHUIS et al., 2001).

Individual risk factors at the animal level are age, breed, lactation stage, hygiene level, production, and somatic cell count in the previous lactation. Mastitis is more common in older animals, some breeds are more prone to mammary gland infections than others in the same holding conditions, and the risk of the occurrence of mastitis is higher in cows kept in a dirty environment, and those with a higher somatic cell count in the last lactation (HIITIÖ et al., 2017).

Mammary gland infections are associated with herd size, and the correlations between the appearance of mastitis and management, milking, feeding, holding conditions, housing and comorbidity with other diseases have also been investigated (OLIVEIRA et al., 2015). 
M. Benić et al.: Bovine mastitis: a persistent and evolving problem requiring novel approaches for its control

\section{Diagnosis of mastitis}

The routine diagnosis of mastitis is based on somatic cell counts and bacteriological testing. In cases of acute mastitis, where clinical changes are evident and the chemical composition of milk is altered, reaching a diagnosis is not difficult, and the milk producer is usually able to detect the problem and the need for treatment.

However, problems arise in cases of subclinical mastitis. Animals affected by this form of mastitis show no clinical signs, and there are no observed changes to the composition of their milk. According to the literature, subclinical mastitis affects some 25 to $50 \%$ of dairy cows, and so the economic impact of subclinical mastitis is far greater than that caused by clinical mastitis (ARGAW, 2016).

To date, numerous methods have been developed to detect mammary gland infections. Since mastitis in cows in most cases passes without any visible clinical signs, reaching the correct diagnosis is often a challenge for veterinarians (RUEGG, 2003).

In the routine diagnosis of mastitis, several methods have been adapted for either field or laboratory use. Clinical examination of the udder has limited value, with the exception of clinical mastitis with changes to the udder. Most casts of intramammary infection are at a subclinical level, and increased somatic cell count is the only indicator of infection (PYORALA, 2003).

Various variations of mastitis tests (California mastitis test, Whiteside test, Brabant test) are based on the effect of a surface active compound on cells in milk. With the rupture of cell membranes, the polymerised DNA is released from the cell nucleus and is transformed into a gel state. The degree of change of the consistency of the mixture of milk and the reagent depends on the somatic cell count in the milk (MAĆEŠIĆ et al., 2016).

Measuring the electrical conductivity of milk is based on the increased concentration of chloride in the secretions of inflamed mammary glands. The conductivity of such milk is altered in comparison to milk from healthy udders (PYORALA, 2003).

Somatic cell counts (SCC). In recent years, progress has been made in techniques to count somatic cells in milk electronically, with the development of mobile devices for somatic cell counts on site at the farm. The SCC of farm samples of milk has become part of the routine quality control of milk in European countries and in the USA (PAŠIĆ et al., 2016).

In research of cell content, the total SCC is quantified, in addition to the ratio of target cell subpopulations. The number of somatic cells has long been used to assess the health status of the mammary gland and to determine the quality of milk, and to set the buyoff price for milk (DOBRANIĆ et al., 2008; SHARMA et al., 2011; PILLA et al., 2012; OLIVEIRA et al., 2015). The ratio of individual cell subpopulations in milk 
is determined using light microscopy in stained smears of cell sediment, or by analysis of cells with marked antibodies in the flow cytometer. The ratios of individual types and subpopulations of cells are also indicators of the health of the gland. It is known that lymphocytes are the dominant cell type in healthy glands, while in infected glands, polymorphic neutrophilic leukocytes are the dominant cell type (SCHWARZ et al., 2011).

Monoclonal antibodies specific for individual subpopulations of leukocytes may be used to quantify the ratio of individual types of leukocytes and their subpopulations in milk. By determining the ratio of individual cell types in milk and their mutual ratios, it is possible to detect the presence of inflammatory processes in the gland, and even to suggest the type of causative agent (BENIĆ et al., 2012a,b).

Measurements of enzyme activity in milk samples are based on the fact that cells of different tissues differ in terms of their enzyme systems. These differences are the result of cellular differentiation and the specific function of individual tissues in the body. For example, the activity of $\mathrm{N}$-acetyl $\beta$-D-glucosaminidase in milk depends on the damage to the epithelial layer in the mammary gland. Increased activity by this enzyme in milk samples indicates damage to gland tissue, since the contribution of leukocytes to the overall activity of that enzyme is very small (MATTILA, 1986).

Microbiological testing is a method that is most often applied in routine diagnostics, and has become the standard test in research on immunological function in the mammary glands. Mastitis diagnostic methods based on the application of gene analysis are becoming more frequent. Gene analysis may be used to test bacteria already isolated from milk, or to detect their presence directly in milk (SPITTEL and HOEDEMAKER, 2012).

Contemporary science aims to identify reliable biomarkers of states of inflammation in the mammary glands, and to use these biomarkers to design new diagnostic tests for the rapid detection of mammary gland infections. Proteomics analysis is one of these tools, based on the quantification of changes in the protein composition of udder secretions, particularly those proteins involved in immunological events (ECKERSALL 2000; ECKERSALL 2004; CECILIANI et al., 2013; FUNMILOLA et al., 2015).

Acute phase proteins (APPs) are proteins that are constructed in the liver during an acute inflammatory reaction (KOVAČ, 2002). The most common bovine APPs of diagnostic value in bovine health disorders are shown in Table 1 (JAWOR and TADEUSZ, 2011). The acute inflammatory reaction is a non-specific and complex response of the organism to infection, trauma, stress or neoplasia. APP is a large and inhomogeneous group of plasma proteins that are released into the blood stream in response to a range of stressors, and they play an important role in protecting the body from pathological damage, in re-establishing homeostasis, and in the regulation of inflammation (ECKERSALL et al., 1996; MURATA et al., 2004; CERON et al., 2005; GRUYS et al., 2005; HUMBELT et al., 2005; KISILEVSKY and MANLEY 2012; TURK et al., 2017). The most important 
M. Benić et al.: Bovine mastitis: a persistent and evolving problem requiring novel approaches for its control

APPs in ruminants are haptoglobin $(\mathrm{Hp})$, serum amyloid A (SAA), fibrinogen and ceruloplasmin (BOOSMAN et al., 1989; GRÖNLUND et al., 2005; VIGUIER et al., 2009; TURK et al., 2012; THOMAS et al., 2015). A correlation has been found between APPs, particularly SAA and Hp, with somatic cell count and bacteriological test results, regardless of whether the mammary gland infection occurs naturally or experimentally (KOVAČEVIĆ FILIPOVIĆ et al., 2012; KLECZKOWSKI et al., 2017). Therefore, SAA and Hp are considered markers that could have diagnostic value (GRUYS et al., 1994; HORADAGODA et al., 1999; GRÖNLUND et al., 2003; PETERSEN et al., 2004; ECKERSALL et al., 2006; GUDEC et al., 2011; EL-DEEB, 2013; TOTHOVA et al., 2014; HADŽIMUSIĆ, 2017).

Table 1. Acute phase proteins (APP) of diagnostic value in common bovine health disorders

(JAWOR and TADEUSZ, 2011)

\begin{tabular}{|l|l|}
\hline Health disorder & APP fractions of diagnostic value \\
\hline $\begin{array}{l}\text { Peripartum reproductive } \\
\text { disorders }\end{array}$ & $\begin{array}{l}\text { Haptoglobin, serum amyloid A (SAA), } \alpha \text { 1-acide glycoproteine } \\
(\alpha 1 \text {-AGP) }\end{array}$ \\
\hline $\begin{array}{l}\text { Abdominal disorders and } \\
\text { surgery }\end{array}$ & Fibrinogen, serum amyloid A (SAA) \\
\hline Mastitis - serum & $\begin{array}{l}\text { Haptoglobin; } \alpha \text {-1 antitrypsin, ceruloplasmin, fibrinogen, acid- } \\
\text { soluble glycoproteins (ASG), } \alpha 1 \text { - proteinase inhibitor }(\alpha 1 \text {-PI) }\end{array}$ \\
\hline Mastitis - milk & Haptoglobin, serum amyloid A \\
\hline Lameness & Haptoglobin, fibrinogen, serum amyloid A \\
\hline
\end{tabular}

\section{Prevention and therapy of mastitis}

The classical approach to mastitis therapy is based on the application of antibiotics during lactation in clinical cases of mastitis, while for subclinical infections, treatment is recommended in the dry period (DJURICIC et al., 2014). Although there are a large number of drugs on the global market for treatment of mastitis, with active compounds from virtually all antibiotic groups, the approaches to treating mastitis are changing. There are multiple reasons behind the research for new therapy approaches. One of the reasons is the increasing frequency of bacterial resistance to antibiotics in human and veterinary medicine, which has led some countries to lay down a legislative framework regulating the cases in which antibiotics should be applied, and which groups of antibiotics may be used in the treatment of mastitis (ESPETVEDT et al., 2013).

The second reason for seeking out a new means to treat mastitis that would be an alternative to antibiotics is changes in the human lifestyle, and the desire to seek out goods produced according to organic principles, from animals not treated with antibiotics, hormones or similar medications. The total ban of dietary AGP in the EU countries since January 1, 2006 (EU Regulation No. 1831/2003) and the elimination of their use in animal feed and/or water in the USA, effective from January 1, 2017 (FDA, CVM 2012, 
VFD Basics 2017) has had a serious influence on both the health and performance of food animals, underlining the need to develop alternative dietary and non-dietary strategies to evaluate the potential antimicrobial agents for replacement of in-feed AGP (GALLOIS et al., 2009; VALPOTIC et al., 2017b).

To date, the alternatives to antibiotics most studied have been zeolites, ozone and propolis (ALIC URAL, 2014; ĐURIČIĆ et al., 2014; ĐURIČIĆ et al., 2015a; BAČIĆ et al., 2016).

Among 140 types of natural zeolites, clinoptilolite is the most widespread scientifically studied substance that incorporates biologically active nanoporous structures spontaneously formed by self-assembly at the molecular level without any human intervention. Therefore it is a very interesting compound on the medical market and has recently been approved in the EU as a feed additive for use as a mycotoxin binder in veterinary medicine, particularly in the livestock, swine and poultry industry (VALPOTIĆ et al., 2017a; VALPOTIĆ et al., 2017b; VALPOTIĆ et al., 2018). In addition, recently, ĐURIČIĆ et al. (2017) evaluated the effects of dietary clinoptilolite (CPL), a novel vibroactivated and micronized modification (Vibrosorb) of the natural mineral, in lactating dairy cows, on milk composition, SCC and the incidence of subclinical mastitis from the third to the seventh month of gestation. No significant differences were observed in the content of milk components, and only the chemical composition of milk was found to be more stable in the CPL-fed cows. Also, the SCC in milk did not differ significantly between the groups. However, the control cows had a 21-fold higher odd of intramammary infections than the CPL-fed cows since these cows had a decreased incidence of intramammary infections during the dry period, parturition and early lactation. The authors concluded that this indicative and beneficial outcome of CPL-supplementation could be attributed to its antibacterial, detoxifying and immunostimulating effects on the incidence of subclinical mastitis and general udder health in dairy cows. More recently, ozone has been used in veterinary medicine, particularly in buiatrics, but still insufficiently (SCROLLAVEZZA et al., 1997; SAMARDŽIJA et al., 2017). Medical ozone therapy has shown effectiveness as an alternative to the use of antibiotics, which are restricted to clinical use and have been withdrawn from non-clinical use as in-feed growth promoters in animal production (ĐURIČIĆ et al., 2015a; SAMARDŽIJA et al., 2017). Moreover, the use of ozone has been considered as a preventive and therapeutic agent in the treatment of ruminant puerperal diseases and for the improvement of reproductive efficiency (DJURICIC et al., 2012a,b; ZOBEL et al., 2012; ĐURIČIĆ et al., 2014; ZOBEL et al., 2014; ĐURIČIĆ et al., 2015b; ĐURIČIĆ et al., 2016).

The application of ozone via infusion into the affected quarter or in the form of a ready-made intramammary preparation has proven to be effective, safe and economical, 
while also completely avoiding the risk of residues appearing in the milk (OGATA and NAGAHATA, 2000; OLIVER et al., 2004; IOFFE and CHERNOVA, 2013).

In recent years, the effects of propolis-based preparations have been examined (CASTALDO and CAPASSO, 2002; SFORCIN and BANKOVA, 2011; FIORDALISI et al., 2016). In vitro testing with an alcohol extract of propolis showed that it reduced the growth capabilities of $S$. aureus. In research to determine the effectiveness of various concentrations of non-alcoholic extracts of propolis, the $1 \%$ solution was shown to have strong antibiotic and antioxidative activity in both in vitro and in vivo conditions (BAČIĆ et al., 2016; ŠURAN et al., 2016).

The mastitis control programmes in dairy cow herds include discovering cows with mastitis, identifying the causative agents, and preventing the spread of the agent by eliminating the source of the infection. Understanding udder anatomy and physiology, defence mechanisms, the sources and virulence of the causative agents, the functioning of milking devices, and the principles of antimicrobial therapy are key factors for the success of control programmes.

\section{Concluding remarks}

Despite preventive measures and therapeutic possibilities, mastitis continues to be the most economically detrimental disease in dairy cow farming. This is the result of the wide range of causative agents, the susceptibility of cows to infection, the environmental conditions cows are kept in, and the risk factors for the emergence of mammary gland infections. Numerous causes of mastitis also have zoonotic potential. Although many methods are currently available for the diagnosis of mastitis, science is still searching for new tests. Research is directed towards new therapeutic procedures that could serve as alternatives to the use of antibiotics.

\section{Acknowledgements}

This work was supported by a grant from the Croatian Scientific Foundation, Zagreb, Croatia for the project no. IP-2014-09-6601, ModZeCow. The principal investigator of the project is Marko Samardžija, DVM, PhD, Full Professor, Faculty of Veterinary Medicine, and University of Zagreb, Croatia.

\section{References}

ALIC URAL, D. (2014): Efficacy of clinoptilolite supplementation on milk yield and somatic cell count. Rev. MVZ Cordoba 19, 4242-4248

DOI: $10.21897 / \mathrm{rmvz} .86$

ARGAW, A. (2016): Review on epidemiology of clinical and subclinical mastitis on dairy cows. Food Sci. Qual. Manag. 52, 56-65. 
M. Benić et al.: Bovine mastitis: a persistent and evolving problem requiring novel approaches for its control

BAČIĆ, G. (2009): Diagnosis and treatment of bovine mastitis. Veterinary Faculty University of Zagreb. (Vince, S., N. Maćešić, Eds.) (in Croatian).

BAČIĆ, G., N. MAČEŠIĆ, L. RADIN, J. ALADROVIĆ, K. MATANOVIĆ, T. MAŠEK, D. BROZIĆ, M. BENIĆ, B. RADIĆ, I. BAČIĆ, J. ŠURAN (2016): Intramammary propolis formulation for prevention and treatment of mastitis in dairy ruminants. J. Anim. Res. 6, 47-49.

DOI: 10.5958/2277-940X.2015.00165.5

BENIĆ, M, B. HABRUN, G. KOMPES, Ž. MIHALJEVIĆ, Ž. CVETNiĆ, M. BRSTILO, M. CERGOLJ, N. MAĆEŠIĆ (2012a): The association of milk cell subsets with management and physiological factors in cows with a natural streptococcal udder infection. Milchwissenschaft 67, 296-299.

BENIĆ, M., B. HABRUN, G. KOMPES, Ž. MIHALJEVIĆ, Ž. CVETNIĆ, M. CERGOLJ, N. MAĆEŠIĆ (2012b): Cell content in milk from cows with S. aureus intramammary infection. Vet. arhiv 82, 411-422.

BENIĆ, M., B. HABRUN, G. KOMPES (2012c): Clinical and epidemiological aspects of cow mastitis caused by $S$. aureus and its methicilin-resistent strains. Rad Hrvatske akademije znanosti i umjetnosti 511 (37) pp. 113-122.

BLOWEY, R., P. EDMONDSON (2010): Mastitis Control in Dairy Herds. $2^{\text {nd }}$ ed. Oxfordshire, United Kingdom: CAB International.

DOI: $10.1079 / 9781845935504.0000$

BOOSMAN, R., T. A. NIEWOLD, C. W. MUTSAERS, E. GRUYS (1989): Serum amyloid A concentrations in cows given endotoxin as an acute-phase stimulant. Am. J. Vet. Res. 50, 16901694.

BREEN, J. E., M. J. GREEN, A. J. BRADLEY (2009): Quarter and cow risk factors associated with the occurrence of clinical mastitis in dairy cows in the united Kingdom. J. Dairy Sci. 92, 2551-2561.

DOI: $10.3168 /$ jds.2008-1369

CASTALDO, S., F. CAPASSO (2002): Propolis, an old remedy used in modern medicine. Fitoterapia 73 (S1), 1-6.

DOI: $10.1016 / \mathrm{S} 0367-326 \mathrm{X}(02) 00185-5$

CECILIANI, F., D. ECKERSALL, R. BURCHMORE, C. LECCHI (2013): Proteomics in veterinary medicine: applications and trends in disease pathogenesis and diagnostics. Vet. Pathol. 51, 351-362.

DOI: $10.1177 / 0300985813502819$

CERON, J. J., P. D. ECKERSALL, S. MARTINEZ-SUBIELA (2005): Acute phase proteins in dogs and cats: current knowledge and future perspectives. Vet. Clin. Pathol. 34, 85-99.

DOI: 10.1111/j.1939-165X.2005.tb00019.x

CVETNIĆ, L., M. SAMARDŽIJA, B. HABRUN, G. KOMPES, M. BENIĆ (2016): Microbiological monitoring of mastitis pathogens in the control of udder health in dairy cows. Slov. Vet. Res. 53, 131-140. 
M. Benić et al.: Bovine mastitis: a persistent and evolving problem requiring novel approaches for its control

DHANASHEKAR, R., A. SINDHURA, N. ARVIND (2012): Milk-borne infections. An analysis of their potential effect on the milk industry. Germs. 2, 101-109.

DOI: $10.11599 /$ germs.2012.1020

DJURICIC, D., S. VINCE, M. ABLONDI, T. DOBRANIC, M. SAMARDZIJA (2012a): Intrauterine ozone treatment of retained fetal membrane in Simmental cows. Anim. Reprod. Sci. 134, 119-124.

DOI: 10.1016/j.anireprosci.2012.08.023

DJURICIC, D., S. VINCE, M. ABLONDI, T. DOBRANIC, M. SAMARDZIJA (2012b): Effect of preventive intrauterine ozone application on reproductive efficiency in Holstein cows. Reprod. Domest. Anim. 47, 87-91.

DOI: 10.1111/j.1439-0531.2011.01805.x

DJURICIC, D., M. SAMARDZIJA, J. GRIZELJ, T. DOBRANIC (2014): Effet du traitement intramammaire des mammites subcliniques pendant la lactation en élevages bovins laitiers au nord-ouest de la Croatie. Ann. Méd. Vét. 158, 121-125.

DOBRANIĆ, V., B. NJARI, M. SAMARDŽIJA, B. MIOKOVIĆ, R. RESANOVIĆ (2008): The influence of the season on the chemical composition and the somatic cell count of bulk tank cow's milk. Vet. arhiv 78, 235-242.

ĐURIČIĆ, D., M. LIPAR, M. SAMARDŽIJA (2014): Ozone treatment of metritis and endometritis in Holstein cows. Vet. arhiv 84, 103-110.

ĐURIČIĆ, D., H. VALPOTIĆ, M. SAMARDŽIJA (2015a): Prophylaxis and therapeutic potential of ozone in buiatrics: Current knowledge. Anim. Reprod. Sci. 159, 1-7.

DOI: 10.1016/j.anireprosci.2015.05.017

ĐURIČIĆ, D., H. VALPOTIĆ, M. SAMARDŽIJA (2015b): The intrauterine treatment of the retained foetal membrane in dairy goats by ozone: novel alternative to antibiotic therapy. Reprod. Domest. Anim. 50, 236-239.

DOI: $10.1111 /$ rda. 12475

ĐURIČIĆ, D., H. VALPOTIĆ, I. ŽURA ŽAJA, M. SAMARDŽIJA (2016): Comparison of Intrauterine Antibiotics versus Ozone Medical Use in Sheep with Retained Placenta and Following Obstetric Assistance. Reprod. Domest. Anim. 51, 538-540.

DOI: $10.1111 /$ rda. 12715

ĐURIČIĆ, D., M. BENIĆ, N. MAĆEŠIĆ, H. VALPOTIĆ, R. TURK, V. DOBRANIĆ, L. CVETNIĆ, D. GRAČNER, S. VINCE, J. GRIZELJ, M. LOJKIĆ, M. SAMARDŽIJA (2017): Effect of dietary clinoptilolite supplementation on somatic cell counts, udder health and chemical composition of milk in Holstein-Frisian cows. Vet. stn. 48, 257-265.

ECKERSALL, P. D. (2000): Recent advances and future prospects for the use of acute phase proteins as markers of disease in animals. Revue de Med. Vet. 151, 577-584.

ECKERSALL, P. D. (2004): The time is right for acute phase protein assays. Vet. J. 168, 3-5. DOI: 10.1016/S1090-0233(03)00165-5 
M. Benić et al.: Bovine mastitis: a persistent and evolving problem requiring novel approaches for its control

ECKERSALL, P. D., F. J. YOUNG, A. M. NOLAN, C. H. KNIGHT, C. McCOMB, M. M. WATERSTON (2006): Acute phase proteins in bovine milk in an experimental model of Staphylococcus aureus subclinical mastitis. J. Dairy Sci. 89, 1488-1501.

DOI: $10.3168 /$ jds.S0022-0302(06)72216-0

ECKERSALL, P. D., P. K. SAINI, C. McCOMB (1996): The acute phase response of acid soluble glycoprotein, alpha(1)-acid glycoprotein, ceruloplasmin, haptoglobin and C-reactive protein in the pig. Vet. Immunol. Immunopathol. 51, 377-385.

DOI: $10.1016 / 0165-2427(95) 05527-4$

EL-DEEB, W. M. (2013): Clinicobiochemical investigations of gangrenous mastitis in does: immunological responses and oxidative stress biomarkers. Zhejiang Univ-Sci B (Biomed \& Biotechnol) 14, 33-39.

DOI: 10.1631 jzus.B1200123

ESPETVEDT, M. N., S. RINTAKOSKI, C. WOLFF, A. K. LindD, A. LINDBERGE, A. M. VIRTALA (2013): Nordic veterinarians' threshold for medical treatment of dairy cows, influence on disease recording and medicine use: Mild clinical mastitis as an example. Prev. Vet. Med. 112, 76-89.

DOI: 10.1016/j.prevetmed.2013.07.004

EZZAT ALNAKIP, M., M. QUINTELA-BALUJA, K. BÖHME, I. FERNÁNDEZ-NO, S. CAAMAÑO-ANTELO, P. CALO-MATA, J. BARROS-VELÁZQUEZ (2014): The immunology of mammary gland of dairy ruminants between healthy and inflammatory conditions. J. Vet. Med., Article ID 659801.

DOI:10.1155/2014/659801

FIORDALISI, S. A. L., L. A. HONORATO, M. R. LOIKO, C. A. M. AVANCINI, M. B. R. VELEIRINHO, L. C. P. M. FILHO, S. KUHNEN (2016): The effects of Brazilian propolis on etiological agents of mastitis and the viability of bovine mammary gland explants. J. Dairy Sci. 99, 2308-2318.

DOI: $10.3168 /$ jds.2015-9777

FUNMILOLA, C., T. MARY WATERSTON, P. HASTIE, T. PARKIN, H. HAINING, P. D. ECKERSALL (2015): The major acute phase proteins of bovine milk in a commercial dairy herd. Vet. Res. 11, 207.

GALLOIS, M, H. J. ROTHKÖTTER, M. BAILEY, C. R. STOKES, I. P. OSWALD (2009): Natural alternatives to in-feed antibiotics in pig production: can immunomodulators play a role? Animal 3, 1644-1661.

DOI: $10.1017 / \mathrm{S} 1751731109004236$

GRAČNER, D., LJ. BEDRICA, M. CERGOLJ, I. HARAPIN, M. SAMARDŽIJA, G. GREGURIĆ GRAČNER, D. ŽUBČIĆ, J. REŠETIĆ, M. FURY (2006): Haptoglobinspielel in Blut und Milch von Kuhen mit einer Staphylokokken mastitis. Tierärtzl. Umschau 61, 636-641. 
M. Benić et al.: Bovine mastitis: a persistent and evolving problem requiring novel approaches for its control

GRÖNLUND, U., C. HALLEN SANDGREN, K. PERSSON WALLER (2005): Haptoglobin and serum amyloid A in milk from dairy cows with chronic sub-clinical mastitis. Vet. Res. 36, 191-198.

DOI: $10.1051 /$ vetres:2004063

GRÖNLUND, U., C. HULTEN, P. D. ECKERSALL, C. HOGARTH, K. PERSSON WALLKER (2003): Haptoglobin and serum amyloid A in milk and serum during acute and chronic experimentally induced Staphylococcus aureus mastitis. J. Dairy Res. 70, 379-386.

DOI: $10.1017 /$ S0022029903006484

GRUYS, E., M. J. M. TOUSSAINT, W. T. A. NIEWOLD, S. J. KOOPMAS (2005): Acute phase reaction and acute phase proteins. J. Zheijang Univ. SCI 6B:1045-1056.

DOI: $10.1631 /$ jzus.2005.B1045

GRUYS, E., M. J. OBWOLO, M. J. M. TOUSSAINT (1994): Diagnostic significance of the major acute phase proteins in veterinary clinical chemistry. Vet. Bull. 64, 1009-1018.

GUARÍN, J. F., M. G. PAIXÃO, P. L. RUEGG (2017): Association of anatomical characteristics of teats with quarter-level somatic cell count. J. Dairy Sci. 100, 1-10.

DOI: $10.3168 /$ jds.2016-11459

GUDEC, A., M. ROBIĆ, M. BELIĆ, R. TURK (2011): Diagnostic value of acute phase proteins in veterinary medicine. Vet. stn. 42, 47-52 (in Croatian).

HADŽIMUSIĆ, N. (2017): C-reactive protein and serum albumin as biomarkers in dogs and humans. Vet. stn. 48, 43-50 (in Croatian).

HIITIÖ, H., J. VAKKAMÄKI, H. SIMOJOKI, T. AUTIO, J. JUNNILA, S. PELKONEN, S. PYÖRÄLÄ (2017): Prevalence of subclinical mastitis in Finnish dairy cows: changes during recent decades and impact of cow and herd factors. Acta Vet. Scand. 59, 22.

DOI: $10.1186 / \mathrm{s} 13028-017-0288-\mathrm{x}$

HORADAGODA, N. U., K. M. G. KNOX, H. A. GIBBS, S. W. J. REID, A. HORAGODA, S. E. R. EDWARDS, P. D. ECKERSALL (1999): Acute phase proteins in cattle: discrimination between acute and chronic inflammation. Vet. Rec. 144, 437-441.

DOI: $10.1136 /$ vr.144.16.437

HUMBELT, M., H. GUYOT, F. MBAYAHI, C. HANZEN, F. ROLLIN, J. GODEAU (2005): Relationship between haptoglobin, serum amyloid A and clinical status in the survey of dairy herds during a six months housing period. The $5^{\text {th }}$ International Colloquium On animal Acute Phase Proteins. Dublin, Ireland. 2005, p. 9.

IOFFE, I. V., N. V. CHERNOVA (2013): Efficacy of application of radiofrequencyscalpel and ozono-ultra-sound method in dynamics of planimetricindices of the wound course process in the patients, suffering anacute purulent lactation mastitis. Klin. Khir. 2, 50-52 (in Russian).

JAWOR P., S. TADEUSZ (2011): Acute Phase proteins in cattle. In: Acute Phase Proteins as Early Non-Specific Biomarkers of Human and Veterinary Diseases, (Veas, F., Ed.), InTech, 
M. Benić et al.: Bovine mastitis: a persistent and evolving problem requiring novel approaches for its control

Available from: https://www.intechopen.com/books/acute-phase-proteins-as-early-nonspecific-biomarkers-of-human-and-veterinary-diseases/acute-phase-proteins-in-cattle .

DOI: $10.5772 / 21154$

KISILEVSKY, R., P. N. MANLEY (2012): Acute-phase serum amyloid A: perspectives on its physiological and pathological roles. Amyloid 19, 5-14.

DOI: $10.3109 / 13506129.2011 .654294$

KLECZKOWSKI, M., W. KLUCIŃSKI, M. CZERSKI, E. KUDYBA (2017): Association between acute phase response, oxidative status and mastitis in cows. Vet. stn. 48, 177-186.

KOVAČ, Z (2002): Inflammations. In: Pathophysiology, (Gamulin S., M. Marušić, Z. Kovač, Eds.) Medicinska naklada, Zagreb. 2002, pp. 471-499 (In Croatian).

KOVAČEVIĆ FILIPOVIĆ, M., V. ILIĆ, Z. VUJČIĆ, B. DOJNOV, M. STEVANOV-PAVLOVIĆ, Z. MIJAČEVIĆ, T. BOŽIĆ (2012): Serum amyloid A isoforms in serum and milk from cows with Staphilococus aureus subclinical mastitis. Vet. Immunol. Immunopathol. 145, 120-128.

DOI: 10.1016/j.vetimm.2011.10.015

LARSEN, H. D., F. M. AARESTRUP, N. E. JENSEN (2002): Geographical variation in the presence of genes encoding superantigenic exotoxins and beta-haemolysin among Staphylococcus aureus isolated from bovine mastitis in Europe and USA. Vet. Microbiol. 85, 61-67.

DOI: 10.1016/S0378-1135(01)00478-3

LAUREANO, M. M., A. B. BIGNARDI, L. EL FARO, V. L. CARDOSO, L. G. ALBUQUERQUE (2012): Genetic parameters for first lactation test-day milk flow in Holstein cows. Animal 6, 31-35.

DOI: $10.1017 / \mathrm{S} 1751731111001376$

LEE, D. H., V. CHOUDHARY (2006): Study on Milkability Traits in Holstein Cows. AsianAustralas J. Anim. Sci. 19, 309-314.

DOI: 10.5713/ajas.2006.309

LYHS, U., L. KULKAS, J. KATHOLM, K. PERSSON WALLER, K. SAHA, R. J. TOMUSK, R. N. ZADOKS (2016): Streptococcus agalactiae Serotype IV in Humans and Cattle, Northern Europe. Emerg. Infect. Dis. 22, 2097-2103.

DOI: $10.3201 /$ eid2212.151447

MAĆEŠIĆ, N., G. BAČIĆ, K. BOŽIČEVIĆ, M. BENIĆ, T. KARADJOLE, N. PRVANOVIĆ BABIĆ, M. LOJKIĆ, M. EFENDIĆ, I. BAČIĆ, M. PAVLAK (2016): Assessment of the Zagreb mastitis test in diagnosis of subclinical mastitis in dairy cattle. Vet. arhiv 86, 475-485

MAĆEŠIĆ, N., T. KARADJOLE, G. BAČIĆ, M. BENIĆ, M. KARADJOLE, S. VINCE, M. LIPAR, M. CERGOLJ (2012): Aetiology and prevalence of bovine intramammary infection at drying off. Vet. arhiv 82, 125-131.

MATTILA, T. (1986): Diagnostic problems in bovine mastitis. Academic disertation, College of Veterinary Medicine, Helsinki. 
M. Benić et al.: Bovine mastitis: a persistent and evolving problem requiring novel approaches for its control

MEIN, G. A. (2012): The role of the milking machine in mastitis control. Vet. Clin. North Am. Food Anim. Pract. 28, 307-320.

DOI: $10.1016 /$ j.cvfa.2012.03.004

MEIN, G. A., D. J. REINEMANN, N. SCHURING, I. OHNSTAD (2004): Milking Machines and Mastitis Risk: A Storm in a Teatcup. Proceedings of the $43^{\text {rd }}$ annual meeting of the National Mastitis Council, USA Charlotte, (NC); Feb 1-4, 2004. pp. 176-188.

MURATA, H., N. SHIMADA, M. YOSHIOKA (2004): Current research on acute phase proteins in veterinary diagnosis: an overview. Vet. J. 168, 28-40.

DOI: 10.1016/S1090-0233(03)00119-9

NEIJENHUIS, F., H. W. BARKEMA, H. HOGEVEEN J. NOORDHUIZEN (2001): Relationship between teat-end callosity and occurrence of clinical mastitis. J. Dairy Sci. 84, 2664-2672.

DOI: $10.3168 /$ jds.S0022-0302(01)74720-0

NYMAN, A. K., T. EKMAN, U. EMANUELSON, A. H. GUSTAFSSON, K. HOLTENIUS, K. P. WALLER, C. H. SANDGREN (2007): Risk factors associated with the incidence of veterinary-treated clinical mastitis in Swedish dairy herds with a high milk yield and a low prevalence of subclinical mastitis. Prev. Vet. Med. 78, 142-160.

DOI: $10.1016 /$ j.prevetmed.2006.10.002

OGATA, A., H. NAGAHATA (2000): Intramammary application of ozonetherapy to acute clinical mastitis in dairy cows. J. Vet. Med. Sci. 62, 681-686.

DOI: $10.1292 /$ jvms.62.681

OLIVER, S. P., B. E. GILlESPIE, S. J. HEADRICK, H. MOOREHEAD, P. LUNN, H. H. DOWLEN, D. L. JOHNSON, K. C. LAMAR, S. T. CHESTER, W. M. MOSELEY (2004): Efficacy of extended ceftiofur intramammary therapy for treatmentof subclinical mastitis in lactating dairy cows. J. Dairy Sci. 87, 2393-2400.

DOI: $10.3168 /$ jds.S0022-0302(04)73361-5

Oliveira, C. S., H. HOGEVEen, A. M. BOtelho, P. V. MAiA, S. G. COELHO, J. P. HADDAD (2015): Cow-specific risk factors for clinical mastitis in Brazilian dairy cattle. Prev. Vet. Med. 121, 297-305.

DOI: 10.1016/j.prevetmed.2015.08.001

OMOE, K., M. ISHIKAWA, Y. SHIMODA, D.-L. HU, S. UEDA, K. SHINAGAWA (2002): Detection of seg, seh, and sei genes in Staphylococcus aureus isolates and determination of the enterotoxin productivities of S. aureus isolates harbouring seg, seh, or sei genes. J. Clin. Microbiol. 40, 857-862.

DOI: 10.1128/JCM.40.3.857-862.2002

PAŠIĆ, V., M. TUDOR KALIT, K. SALAJPAL, D. SAMARŽIJA, J. HAVRANEK, S. KALIT (2016): The impact of changes in the milk payment system and season on the hygienic quality of milk. J. Cent. Eur. Agricult. 17, 629-639.

DOI: $10.5513 /$ JCEA01/17.3.1755

Vet. arhiv 88 (4), 535-557, 2018 
M. Benić et al.: Bovine mastitis: a persistent and evolving problem requiring novel approaches for its control

PAVLAK, M., M. BENIĆ, D. CVITKOVIĆ, M. TADIĆ (2008): Epidemiology of bovine mastitis - analysis of published data and comparison with bovine udder health status in Croatia. Proceedings of the XVI. Congress of the Mediterranean Federation for Health and Production of Ruminanst (FeMeSPRum), Zadar, Croatia. pp. 97-112.

PETERSEN, H. H., J. P. NIELSEN, P. M. HEEGAARD (2004): Application of acute phase protein measurements in veterinary clinical chemistry. Vet. Res. 35, 163-187.

DOI: $10.1051 /$ vetres:2004002

PETERSSON-WOLFE, C. S. (2010): Staphylococcus aureus mastitis: cause, detection, and control. VCE Publications 404/404-229.

PETROVSKI, K. R., M. TRAJCEV, G. BUNESKI (2006): A review of the factors affecting the costs of bovine mastitis. J. S. Afr. Vet. Assoc. 77, 52-60.

DOI: 10.4102 jsava.v77i2.344

PILLA, R., D. SCHWARZ, S. KÖNIG S, R. PICCININI (2012): Microscopic differential cell counting to identify inflammatory reactions in dairy cow quarter milk samples. J. Dairy Sci. 95, 4410-4420.

DOI: $10.3168 /$ jds.2012-5331

PYÖRÄLÄ, S (2003): Indicators of inflammation in the diagnosis of mastitis Vet. Res. 34 565-578. DOI: $10.1051 /$ vetres:2003026

RAINARD, P., C. RIOLLET (2006): Innate immunity of the bovine mammary gland. Vet. Res. 37, 369-400.

DOI: $10.1051 /$ vetres:2006007

REINEMANN, D. J. (2010): Advances in machine milking: the inflence of milking on teat condition and mastitis risk. International All-Stars Mastitis Control Symposium. Melbourne, 30 March 2010, pp. 28-31.

REINEMANN, D. J. (2012): Stray Voltage and Milk Quality. Vet. Clin. North Am. Food Anim. Pract. 28, 321-345.

DOI: 10.1016/j.cvfa.2012.03.008

RÉMOND, B., D. POMIÈS (2005): Once-daily milking of dairy cows: a review of recent French experiments. Anim. Res. 54, 427-442.

DOI: 10.1051/animres:2005040

RUEGG, P. L. (2003): Investigation of mastitis problems on farms. Vet. Clin. Food Anim. 19, 47-73.

DOI: 10.1016/S0749-0720(02)00078-6

SAMARDŽIJA, M., R. TURK, P. SOBIECH, H. VALPOTIĆ, I. HARAPIN, D. GRAČNER, D. ĐURIČIĆ (2017): Intrauterine ozone treatment of puerperal disorders in domestic ruminants: a review. Vet. arhiv 87, 363-375.

DOI: $10.24099 /$ vet.arhiv.160119a

SCHWARZ, D., U. S. DIESTERBECK, S. KÖNIG, K. BRÜGEMANN, K. SCHLEZ, M. ZSCHÖCK, W. WOLTER, C. P. CZERNY (2011): Flow cytometric differential cell counts 
M. Benić et al.: Bovine mastitis: a persistent and evolving problem requiring novel approaches for its control

in milk for the evaluation of inflammatory reactions in clinically healthy and subclinically infected bovine mammary glands. J. Dairy Sci. 94, 5033-5044.

DOI: $10.3168 /$ jds.2011-4348

SCROLLAVEZZA, P., M. ABLONDI, B. POGLIACOMI, D. GUARESCHI, R. DALL'AGLIO, R. POLDI, G. PEZZOLI (1997): Ozone treatment in mastites, metrites and retention of fetal membranes in the cows. Atti 2 Intern. Symp. Ozone Application, Havana, Cuba.

SEARS, M. P., K. McCARTHY (2003): Diagnosis of mastitis for therapy decisions. Vet. Clin. Food Anim. 19, 93-108.

DOI: $10.1016 /$ S0749-0720(02)00074-9

SFORCIN, J. M., V. BANKOVA (2011): Propolis: Is there a potential for the development of new drugs? J. Ethnopharmacol. 133, 253-260.

DOI: $10.1016 /$ j.jep.2010.10.032

SHAHEEN, M., H. A. TANTARY, S. U. NABI (2016): A treatise on bovine mastitis: disease and disease economics, etiological basis, risk factors, impact on human health, therapeutic management, prevention and control strategy. J. Adv. Dairy Res. 4, 150.

SHARMA, N., N. K. SINGH, M. S. BHADWAL (2011): Relationship of somatic cell count and mastitis: an overview. Asian-Aust. J. Anim. Sci. 24, 429-438.

SPITTEL S., M. HOEDEMAKER (2012): Mastitis diagnosis in dairy cows using PathoProof realtime polymerase chain reaction assay in comparison with conventional bacterial culture in a Northern German field study. Berl. Munch. Tierarztl. Wochenschr. 125, 494-502.

ŠURAN, J., K. MATANOVIĆ, D. BROZIĆ, T. MAŠEK, N. MAĆEŠIĆ, L. RADIN, J. ALADROVIĆ, F. BOŽIĆ, B. ŠEOL MARTINEC, M. LIPAR, O. SMOLEC, M. BENIĆ, B. RADIĆ, G. BAČIĆ (2016): Antimicrobial activity of propolis and its potential uses in veterinary medicine. Vet. stn. 47, 381-385 (in Croatian).

TÄNAVOTS, A., H. KIIMAN, E. ALTOSAAR, T. KAART, H. VIINALASS (2015): Milk leakage from the udder of cows on dairy farms with automatic and conventional milking system. Vet. Med. Zoot. 69, 71-78.

THOMAS, F. C., M. WATERSTON, P. HASTIE, T. PARKIN, H. HAINING, P. D. ECKERSALL (2015): The major acute phase proteins of bovine milk in a commercial dairy herd. BMC Vet. Res. 11, 207.

DOI: $10.1186 / \mathrm{s} 12917-015-0533-3$

TOPOLKO, S., M. BENIĆ (1997): Actual problems and epizootiological status of subclinical mastitis in small scale dairy farming. Praxis vet. 45, 69-76 (in Croatian).

TOTHOVA, C., O. NAGY, G. KOVAC (2014): Acute phase proteins and their use in the diagnosis of diseases in ruminants: a review. Vet. Med. 59, 163-180.

DOI: 10.17221/7478-VETMED

TURK, R., C. PIRAS, M. KOVAČIĆ, M. SAMARDŽIJA, H. AHMED, M. DE CANIO, A. URBANI, Z. FLEGAR MEŠTRIĆ, A. SOGGIU, L. BONIZZI, P. RONCADA (2012): 
M. Benić et al.: Bovine mastitis: a persistent and evolving problem requiring novel approaches for its control

Proteomics of inflammatory and oxidative stress response in cows with subclinical and clinical mastitis. J. Proteomics 75, 4412-4428.

DOI: $10.1016 /$ j.jprot.2012.05.021

TURK, R., M. KOLEDIĆ, N. MAĆEŠIĆ, M. BENIĆ, V. DOBRANIĆ, D. ĐURIČIĆ, L. CVETNIĆ, M. SAMARDŽIJA (2017): The role of oxidative stress and inflammatory response in the pathogenesis of mastitis in dairy cows. Mljekarstvo 67, 91-101.

DOI: $10.15567 / \mathrm{mljekarstvo.2017.0201}$

VAKKAMÄKI, J., S. TAPONEN, A. M. HEIKKILÄ S. PYÖRÄLÄ (2017): Bacteriological etiology and treatment of mastitis in Finnish dairy herds. Acta Vet. Scand. 59, 33.

DOI: $10.1186 / \mathrm{s} 13028-017-0301-4$

VALPOTIĆ, H., R. BARIĆ-RAFAJ, V. MRLJAK, Ž. GRABAREVIĆ, M. SAMARDŽIJA, M. ŠPERANDA, I. ŽURA ŽAJA, D. ĐURIČIĆ, A. BACH, I. HARAPIN, I. FOLNOŽIĆ, S. VINCE, I. VALPOTIĆ (2017a): Influence of dietary mannan oligosaccharide and clinoptilolite on hematological, biochemical and gut histological parameters in weaned pigs. Period. biol. 119, 63-73.

DOI: $10.18054 /$ pb.v119i1.4407

VALPOTIĆ, H., D. GRAČNER, R. TURK, D. ĐURIČIĆ, S. VINCE, I. FOLNOŽIĆ, M. LOJKIĆ, I. ŽURA ŽAJA, LJ. BEDRICA, N. MAĆEŠIĆ, I. GETZ, T. DOBRANIĆ, M. SAMARDŽIJA (2017b): Zeolite clinoptilolite nanoporous feed additive for animals of veterinary importance: potentials and limitations. Period. biol. 119, 159-172.

DOI: 10.18054/pb.v119i3.5434

VALPOTIĆ, H., I. ŽURA ŽAJA, M. SAMARDŽIJA, B. HABRUN, M. OSTOVIĆ, D. ĐURIČIĆ, N. MAĆEŠIĆ, Ž. MIKULEC, P. KOČILA, P. SOBIECH, I. VALPOTIĆ, S. VINCE (2018): Dietary supplementation with mannan oligosaccharide and clinoptilolite modulates innate and adaptive immune parameters of weaned pigs. Pol. J. Vet. Sci. 21, 83-93.

DOI: $10.24425 / 119025$

VIGUIER, C., S. ARORA, N. GILMARTIN, K. WELBECK, R. O'KENNEDY (2009): Mastitis detection: current trends and future perspectives. Trends Biotechnol. 27, 486-493.

DOI: 10.1016/j.tibtech.2009.05.004

WONG, A. C. L., M. S. BERGDOLL (2002): Staphylococcal food poisoning. In: Foodborne Diseases, (Cliver, D. O., H. P. Riemann, Eds.), Academic Press Amsterdam, 2002, pp. 231-248.

ZADOKS, R. N., J. R. MIDDLETON, S. McDOUGALL, J. KATHOLM, Y. H. SCHUKKEN (2011): Molecular epidemiology of mastitis pathogens of dairy cattle and comparative relevance to humans. J. Mammary Gland Biol. Neoplasia 16, 357-372.

DOI: $10.1007 / \mathrm{s} 10911-011-9236-\mathrm{y}$

ZSCHÖCK, M, B. KLOPPERT, W. WOLTER, H. P. HAMANN, C. LÄMMLER (2005): Pattern of enterotoxin genes seg, seh, sei and sej positive Staphylococcus aureus isolated from bovine mastitis. Vet. Microbiol. 108, 243-249.

DOI: 10.1016/j.vetmic.2005.02.012 
M. Benić et al.: Bovine mastitis: a persistent and evolving problem requiring novel approaches for its control

ZOBEL, R., S. TKALČIĆ, I. ŠTOKOVIĆ, I. PIPAL, V. BUIĆ (2012): Efficacy of ozone as a novel treatment option for urovagina in dairy cows. Reprod. Domest. Anim. 47, 293-298.

DOI: 10.1111/j.1439-0531.2011.01857.x

ZOBEL, R., R. MARTINEC, D. IVANOVIĆ, N. ROŠIĆ, Z. STANČIĆ, I. ŽERJAVIĆ, B. FLAJSIG, H. PLAVEC, O. SMOLEC (2014): Intrauterine ozone administration for improving fertility rate in Simmental cattle. Vet. arhiv 84, 1-8.

\section{BENIĆ, M., N. MAĆE ŠIĆ, L. CVETNIĆ, B. HABRUN, Ž. CVETNIĆ, R. TURK, D. ĐURIČIĆ, M. LOJKIĆ, V. DOBRANIĆ. H. VALPOTIĆ, J. GRIZELJ, D. GRAČNER, J. GRBAVAC, M. SAMARDŽIJA: Mastitis u goveda: trajni i ponavljajući problem koji zahtijeva nove pristupe za njegovu kontrolu - pregledni članak. Vet. arhiv 88, 535-557, 2018. \\ SAŽETAK}

Mastitis mliječnih krava jest upala mliječne žlijezde i najvažniji je uzrok ekonomskih gubitaka u suvremenoj mliječnoj industriji. Najčešće je infektivne naravi, a može ga prouzročiti 150 različitih vrsta mikroba. Okoliš krave naseljen je obiljem mikrobiota, a mlijeko je idealna podloga za razmnožavanje bakterija i ostalih uzročnika. Najčešći uzročnik mastitisa izoliran iz mliječne žlijezde jest Staphylococcus aureus, koji može prouzročiti zdravstvene poremećaje i u ljudi. Mlijeko iz inficirane mliječne žlijezde kemijski je promijenjeno u odnosu na mlijeko iz zdrave četvrti. Neke od promjena, poput komponenti proteina karakterističnih za upale tkiva, znanost pokušava iskoristiti za dizajniranje novih dijagnostičkih testova za otkrivanje mastitisa. Dosad identificirani čimbenici rizika za mastitis mogu utjecati na njegovu pojavnost na razini četvrti, pojedine krave te stada. Liječenje mastitisa uključuje preventivne i terapijske mjere uglavnom pomoću antibiotika. U novije se vrijeme terapijski pristup mijenja uvođenjem prirodnih ljekovitih sredstava poput zeolita, ozona i propolisa, koji su potencijalne alternative antibioticima.

Ključne riječi: mastitis; stanje spoznaja; noviji pristupi kontrole; mliječna krava 
